\title{
Nutritional adequacy of meals offered and consumed by soldiers of the Brazilian Army
}

\author{
Adequação nutricional de oferta e \\ consumo de refeições por \\ soldados brasileiros
}

Raquel Braz Assunção BOTELHO'

Fernanda AVENA ${ }^{1}$

Mariana VERAS 1

Renata Puppin ZANDONADI ${ }^{1}$

A B S T R A C T

\section{Objective}

The purpose of this research is to evaluate the nutritional adequacy of meals served and consumed by soldiers in a construction unit (army and civil employees) of the Brazilian Army Construction.

\section{Methods}

Body mass index, fat percentage (bioimpedance) and the physical activity level were evaluated. Furthermore, the nutritional evaluation of meals offered and consumed by soldiers was evaluated, in relation to the macronutrients, sodium, fibers and total energetic value.

\section{Results}

Through the results, we verified that $76 \%$ of the soldiers were eutrophic, and that the population's energetic requirement was approximately $3.600 \mathrm{kcal}$. We verified that the energetic consumption of this population was below the required value $(3.200 \mathrm{kcal})$ and with inadequacy regarding the distribution of macronutrients: percentage of carbohydrates above the recommended one, percentage of lipid below the minimum value recommended and percentage of proteins within the recommendation. Moreover, the amount of fibers was in accordance to the standards; however, there was an excessive amount of sodium, which may put this population in danger.

\footnotetext{
1 Universidade de Brasília, Escola de Ciências da Saúde, Departamento de Nutrição. Campus Universitário Darcy Ribeiro, Asa Norte, 70910-900, Brasília, DF, Brasil. Correspondência para/Correspondence to: RBA BOTELHO. E-mail: <raquelbotelho@terra.com.br>.

Support: The research received financial support for translation by the Universidade de Brasilia (Edital DPP/UnB 05/2012).
} 


\section{Conclusion}

We concluded that it is necessary to improve the quality of the meals offered in relation to the nutritional aspect, by promoting the adequacy to the soldiers' needs. Other types of quality were not studied, but they are important when evaluating acceptability of meals.

Indexing terms: Food composition. Food consumption. Military personnel. Nutrition assessment.

\section{R E S U M O}

\section{Objetivo}

O objetivo do presente trabalho foi avaliar a adequação nutricional de refeições oferecidas e consumidas por soldados do Exército Brasileiro em uma unidade de construção.

\section{Métodos}

Para avaliar a demanda energética e de nutrientes para o grupo estudado, foram avaliados o índice de massa corporal, o percentual de gordura (bioimpedância) e o nível de atividade física. Ademais, avaliaram-se nutricionalmente (macronutrientes, sódio, fibras e valor energético total) as refeições ofertadas aos soldados e por eles consumidas.

\section{Resultados}

Verificou-se por meio dos resultados que $76 \%$ dos soldados estavam eutróficos e que a demanda energética média da população estudada foi de 3600 kcal, porém o consumo energético (3200 kcal) estava abaixo do valor necessário e com inadequação em relação à distribuição de macronutrientes: percentual de carboidratos acima do recomendado; percentual de lipídios abaixo do recomendado. O percentual de proteínas estava de acordo com a recomendação. Verificou-se, também, que havia consumo adequado em relação à quantidade de fibras, porém com excesso de sódio, o que pode representar um risco à população estudada.

\section{Conclusão}

É necessário melhorar a qualidade das refeições ofertadas em relação ao aspecto nutricional a fim de se promover adequação às necessidades dos soldados. Outros tipos de qualidade - sensorial, higiênico-sanitária, regulamentar, entre outras -, não foram avaliados, mas são importantes para se verificar a aceitabilidade das refeições.

Termos de indexação: Composição de alimentos. Consumo de alimentos. Militares. Avaliação nutricional.

\section{NTROD UCTION}

In the Armed Forces, the military has to obey a series of disciplinary norms and hierarchical principles that they will follow for their entire professional life. In this process, the soldier represents the lowest patent. Usually, in course of his work the demand of energy expenditure is very high, for example during trainings for war, jobs in defense of the native country in its boundaries, engineering missions and construction ${ }^{1}$.

For soldiers, the nutritional adequacy of meals is one of the most important conditions for physical and mental support, mainly in the sustenance of the exhausting work that is required throughout the day. Balanced food intake must provide daily energy and nutrients required for the optimal body functioning ${ }^{2,3}$ and is related to various factors from preparation of food until intake. Among the factors related to intake are cultural and religious habits, social status, familiar memory and guarantee of survival ${ }^{4}$, factors directly related to nutritional and food security. This type of security predicts regular access to food in quality and quantity without compromising access to other essential needs. It is based on food practices that promote health, respecting cultural diversity, and on a sustainable environment ${ }^{3}$.

Proper nutritional meals are important for soldiers in order to increase or maintain their performance at work $^{5}$, requiring specific caloric and nutrient contributions that may vary by 
gender, age and body composition ${ }^{6}$. There is a disparity between nutrients routinely consumed by the public and the recommended dietary intake for good health. This gap also exists in the intakes of military personnel7 ${ }^{7}$. In many military missions that require great physical effort, such as training for war, works at borders, and missions, the demand for nutrients and energy is increased and all these factors are not always observed in the meals destined for this population.

When the dietary intake is not enough in order to fulfill the nutritional demand, loss of lean body mass may occur, resulting in the decrease of strength, which itself may promote the development of diseases arising from the deficiency of nutrients ${ }^{8}$.

The knowledge concerning the energy requirements and nutritional demand is important in order to determine the nutritional composition of meals offered to soldiers to maintain health and prevent diseases, whilst ensuring the quality of their work?

Therefore, the purpose of this research is to evaluate the nutritional adequacy of meals served and consumed by soldiers in a construction unit (army and civil employees) of the Brazilian Army.

\section{METHODS}

This is an exploratory study, which is also transversal and subdivided in five steps: determination of the physical composition of soldiers; evaluation of energy expenditure of soldiers; evaluation of adequacy of nutrients offered; evaluation of adequacy of nutrients consumption and statistical analysis of data. This research was approved by the Committee of Ethics in Research Involving Human Beings of the Universidade de Brasilia (UnB) (Record 0183.0.012.000-08).

The study population was composed of masculine soldiers, since women are not incorporated in this patent for the Brazilian Army.
The sample of the soldiers that took part in this study was calculated based on soldiers' population that had their meals at their work stations - a construction unit (army and civil employees) of the Brazilian Army located in the Brazilian Northeast, a place far from the commerce and housing zones. In this place, there is a meal production unit that serves five daily meals for military: breakfast, morning snack, lunch, dinner and late evening snack.

For the calculation of the sampling plan, a statistical study of simple random sampling was carried out based on the soldiers' population $(n=396)$ at a significance level of $(\alpha) 5 \%{ }^{10}$. The size of the sample was 92 individuals.

\section{Determination of the physical composition}

In order to determine and evaluate the physical composition, the following data was used: weight, height, date of birth and percentage of body fat.

For the diagnosis of the nutritional state of this population, the calculation of Body Mass Index (BMI) was used, and its classification according to the criteria adopted by the World Health Organization $(\mathrm{WHO})^{11}$. The measurement of the body fat percentage was done, since this is a population with intense physical activity (average daily physical activity of 12 hours) as well as for the fact that the BMI is an index that does not differ between muscular mass (lean mass), adipose tissue and bone mass. The used method was bioimpedance; a non-invasive method that evaluates the body composition based on natural conduction of low intensity electrical current. The result expressed in resistance and reactance is transformed in to adipose tissue percentage through specific equations ${ }^{12}$.

In order to measure the weight and height, the protocol of Jeliffe's ${ }^{13}$ was used, through a Tech Line ${ }^{\circledR}$ scales with $150 \mathrm{~kg}$ capacity with accuracy of $100 \mathrm{~g}$ and a Tech Line ${ }^{\circledR}$ stature meter, with accuracy of half a centimeter. 
In order to obtain tetra-pole electrical Bioimpedance Analysis (BIA), TBW ${ }^{\circledR}$ equipment and measurement procedures were used as per Rossi's \& Tirapegui's protocol ${ }^{12}$. The evaluation was carried out before the beginning of the daily work activities. The soldiers were oriented to be eight hour fasting and not to consume any alcoholic beverage in the previous night.

\section{Evaluation of the energy expenditure}

The Physical Activity Level (PAL) was evaluated in accordance with the WHO protocol ${ }^{12}$. The analysis of the physical activity level of the population according to the duration of the daily activities is important as to enable estimation of the total energy expenditure, taking into account the age, gender and body weight of the individuals.

The participants were inquired as for the duration of their daily activities (beyond the physical activities), such as sleep hours, working hours, leisure time, commuting, (kind of activity and duration) ${ }^{14}$. PAL was determined by the duration of the performed daily activities reported by the sample, in order to determine the energetic expenditure. For the remaining time with routine activities that were not reported, a factor of 1.4 was used in accordance with the FAO/WHO table ${ }^{14}$; multiplying it by Basal Metabolic Rate (BMR) and by the number of hours of that period. The sum of the partial activities was divided by 24 hours in order to obtain the PAL per day. The estimated value of PAL was used for each individual in a multiple regression model ${ }^{15}$. This obtained data was used for determining the individual's energy requirements ${ }^{15}$ through calculation of the Estimated Energy Requirement (EER). In order to calculate EER for men, the following formula was used: $E E R=662-9.53 x a g e$ (years)+PALx(15.91xweight [kg]+539.6xheight [m]).

\section{Evaluation of the adequacy of the offer and of the nutrients consumption}

In order to determine the supply of nutrients, the Technical Preparation Files (TPF) were initially developed for each component of the offered meals (breakfast, morning snack, lunch, dinner and late evening snack) during three consecutive days according to the model proposed by Camargo \& Botelho ${ }^{16}$. Therefore, all steps of pre-preparation and preparation were monitored by checking the preparation techniques and ingredients used for each preparation, which enables to determine the amount of each ingredient used, for later calculation of the nutritional composition of the preparation.

The evaluated meals were made in the Army unit by employees of the foodservice. However, the distribution manner is differentiated: breakfast is served in the refectory; morning snack is distributed for each soldier in each stretch of the work; lunch is served in disposable bowls, transported and distributed to soldiers; meals, during the evening, are distributed in the refectory and soldiers serve themselves ${ }^{17}$.

For the calculation of the nutritional composition of the offered meals the 2008 Dietwin ${ }^{\circledR}$ software was used, containing the Brazilian Table of Food Composition ${ }^{18}$. For the food that is not included in the data base of the aforementioned table, the ingredient label was used as a reference.

After the preparation of TPF, the empty disposable bowl was weighed, and while it was filled with each preparation by the foodservice's employees for the calculation of the offer, without interference of the team of researchers. Afterwards it was numbered and forwarded to each soldier that took part in the sample. After the meal, the metal bowls were collected and weighed for determination of the remaining portion.

For the determination of the remaining portion, the waste weight was collected in the 
metal pans, by excluding the non-eatable material (bones, peels, seeds).

In order to evaluate the offer and intake of dinner, the methodology proposed by Sávio et al. ${ }^{19}$ was used. In this method, all preparations are priory weighed using their utensils and, researchers directly observe each individual while serving each preparation. Therefore, the meals were served in the refectory by self-service mode during the evening. Thus, the preparations served with its respective portion were recorded in order to determine the ratio of each preparation put in the plates. Afterwards, the meal of each individual (made plate) was weighed. The participant soldiers were informed that if they wanted to repeat the meal, they should inform the team so that a new plate was weighed.

Once the weighing of the final plate was done, a numbered label was put under the plate for each participant.

From the data of the individual weight of the metal bowl or the plate and the respective remaining portion, the remaining portion index was obtained. The Ingestion Remaining Portion Index (IR) was calculated in accordance with the model proposed by Abreu et al. ${ }^{20}$, by dividing the weight of the rejected meal by the weight of the distributed meal, multiplying by 100 . For the preparations of breakfast, morning snack and late evening snack, there were no remaining portion.

In order to identify if the offer and the energy consumption were appropriate, the EER ${ }^{15}$ was compared to the average estimated energy value of meals served per individual and also to the consumed energy value.

The evaluation of the adequacy of nutrients offered (total carbohydrates - 45\% to $65 \%$, proteins - $10 \%$ to $35 \%$, lipids - $20 \%$ to $35 \%$ ) was determined by comparison to the ingestion recommendations ${ }^{21}$. For the evaluation of the adequacy of fibers offered, the data was compared to the Brazilian recommendations of the Ministry of Health $(25 \mathrm{~g} / \text { day })^{22}$. The amounts of sodium of the offered meal were compared to the maximum amount of ingestion, determined by the Institute of Medicine $(2.300 \mathrm{mg} / \text { day })^{15}$.

\section{Statistical analysis}

The statistical analyses of the descriptive data (frequency, average, percentage, standard deviation) were done for characterization of the sample, by using MS Excel ${ }^{\circledR}$.

In order to do a comparison between BMI and fat percentage, Pearson's Linear Correlation Coefficient ( $r$ ) was used, which is the measure used to evaluate the linear correlation strength between two random variables. The coefficient varies from -1 to $1 ;-1$ perfect negative linear correlation, that is, as one variable increases the other one decreases ${ }^{23}$. This comparison was performed in order to check if BMI classification was reliable, since soldiers, because of intense physical activity, can present weight excess from muscle weight.

In order to compare IR, the normality test Kolgomorov-Simirnova was conducted on sample. Afterwards, Student's $t$ test was applied to determine difference from lunch and dinner waste.

\section{RESULTS AND DISCUSSION}

\section{Characterization of the population and evaluation of the physical composition}

In Table 1, the average age and anthropometrical data of the studied population is shown. The average age of soldiers was $20 \pm 1.8$ years old; the majority of them was 20 years old or younger. In accordance with the classification of $\mathrm{BMI}^{11}$, we verified that $76.5 \%$ of the soldiers are eutrophic, $4.0 \%$ of the soldiers showed low weight and $19.5 \%$ showed overweight. This approaches the Brazilian average, which is $23.0 \%$ of obesity prevalence in individuals of the male gender between 18 and 24 years old ${ }^{24}$. 
Table 1. Characterization of the study population. Brazilian Army soldiers, Brazil, 2011.

\begin{tabular}{lrrrr}
\hline Parameters & Average & Minimum & Maximum & Standard Deviation \\
\hline Age & 20.04 & 18.00 & 26.00 & 1.80 \\
Weight & 68.74 & 49.60 & 103.40 & 1.91 \\
Height & 1.72 & 1.60 & 32.30 & 0.06 \\
BMl & 23.10 & 16.20 & 30.80 & 3.00 \\
Fat \% & 13.76 & 3.70 & 5.14 \\
\hline
\end{tabular}

Note: BMI: Body Mass Index.

Studies confirm that only the use of BMI in order to evaluate the individual's nutritional state does not reflect the reality, therefore it is not possible to determine the body composition ${ }^{25}$. Thus, we can highlight that the average fat percentage measured in this population by the bioimpedance method was $13.76 \pm 5.14 \%$. The fat percentage recommended for the male gender at this age is up to $16.00 \%$ of the total body fat. Possibly, the low average fat percentage found among soldiers is a reflection of the enhanced physical activity level practiced.

Nevertheless, $32 \%$ of the individuals showed fat percentage higher than the recommendation for their age (16\%). Correlating to the BMI data and fat percentage, we can observe that among the individuals that are overweight ( $\mathrm{BMI}>25.0$ ), 73\% showed fat percentage above the recommended value, which was already expected. The other $27 \%$ obtained a fat percentage below 16 , which indicates that these individuals show great muscular mass and they should not be classified the same as the other individuals that are overweight. Therefore, considering the association between $\mathrm{BMI}$ and fat percentage, only $14 \%$ of the evaluated individuals could be classified with an inadequate weight because they showed at the same time high fat percentage.

Studies ${ }^{25,26}$ corroborate the obtained result, by showing the occurrence of overweighed individuals (according to BMI) associated with low body fat percentages due to higher muscular mass concentration.

Although $27 \%$ of the individuals classified by BMI were overweight and they had fat percentage in the recommended value, we verified that there is a correlation between weight and fat percentage $(r=0.69)$, indicating that heavier soldiers have greater fat percentage. We also observed that individuals that showed BMI classification for obesity showed high fat percentage as well. Thus, the evaluation for this group through BMI determination is a good parameter for the nutritional state analysis.

\section{Evaluation of soldiers' energy expenditure}

Considering the anthropometrical characteristics and the physical activity level of the studied population, we can conclude that EER estimated for the population is approximately $3.636 \pm 359 \mathrm{kcal}$. In the study carried out by Montain \& Young ${ }^{27}$ which was done with American soldiers at the same physical activity level and equivalent age, a similar need of energy (3.600 kcal) was found.

\section{Evaluation of the offer and of the nutrients consumption}

Table 2 shows the menu for three days with average weight of the portions that were offered to the soldiers throughout the day. The served breakfast was composed of coffee with milk, bread, margarine, some type of spread for the bread and, occasionally, a fruit. At snack time, artificial juice (cold drink) and bread with varied filling were offered. Lunch and dinner were composed of one type of meat (main course), one 
Table 2. Three-day Daily Menu with average weighed of offered portions. Brazil, 2011.

\begin{tabular}{|c|c|c|c|c|c|c|}
\hline \multirow[b]{2}{*}{ Menu } & \multicolumn{2}{|l|}{$1^{\text {st }}$ day } & \multicolumn{2}{|l|}{$2^{\text {nd }}$ day } & \multicolumn{2}{|l|}{$3^{\text {rd }}$ day } \\
\hline & Preparations & $\begin{array}{l}\text { Average } \\
\text { portion }(\mathrm{g})\end{array}$ & Preparations & $\begin{array}{c}\text { Average } \\
\text { portion (g) }\end{array}$ & Preparations & $\begin{array}{l}\text { Average } \\
\text { portion }(\mathrm{g})\end{array}$ \\
\hline & White bread & 61 & White bread & 64 & White bread & 64 \\
\hline & Bologna sausage & 40 & Sausage & 68 & Toast & 34 \\
\hline \multirow[t]{4}{*}{ Breakfast } & Margarine & 5 & Watermelon & 80 & Banana & 123 \\
\hline & Coffee & 123 & Banana & 123 & Coffee & 123 \\
\hline & Whole milk & 247 & Coffee & 123 & Whole milk & 247 \\
\hline & & & Whole milk & 247 & & \\
\hline \multirow{4}{*}{ Snack } & Toast with margarine and & 50 & White bread & 30 & Sweet bread & 88 \\
\hline & oregano & & Sweet bread & 44 & White bread & 30 \\
\hline & Sweet bread & 166 & Bologna sausage & 20 & Sausage with sauce & 68 \\
\hline & Artificial soursop juice & 200 & Artificial mango juice & 300 & Artificial soursop juice & 200 \\
\hline \multirow{5}{*}{ Lunch } & Chicken with vegetables & 164 & Meat with vegetables & 141 & Meat with pumpkin & 141 \\
\hline & Macaroni with garlic and oil & 110 & Macaroni with garlic and oil & 85 & Macaroni & 89 \\
\hline & Olives & & & & & \\
\hline & Brown beans with sausage & 138 & Mashed potatoes & 63 & White rice & 288 \\
\hline & $\begin{array}{l}\text { Rice (white rice, grapes, } \\
\text { carrot and peas) }\end{array}$ & 350 & White rice & 331 & Brown beans & 159 \\
\hline \multirow{4}{*}{ Dinner } & Chicken with vegetables & 103 & Brown beans & 172 & Beef stroganoff & 105 \\
\hline & White rice & 355 & Meat with vegetables & 110 & White rice & 314 \\
\hline & Brown beans with sausage & 72 & White rice & 368 & Brown beans & 93 \\
\hline & & & Brown beans with sausage & 70 & & \\
\hline
\end{tabular}

garnish, white rice and brown beans (since this is a Brazilian consumption habit) and, sporadically, raw salad.

By analyzing the three-day menu (Table 2), we can observe little variety in the meals. The repetition of dishes offered at lunch and dinner is common in the studied unit. Therefore, the food volume prepared in the morning considers these two meals. The food storage of food ready for consumption and the food that was not prepared yet is improperly done, in locations with inappropriate temperature. This results in major loss of raw material and the possibility of spreading microorganisms in the prepared meals, which makes the consumption of this food dangerous both at lunch and dinner ${ }^{28}$.

We can observe that the offer of cooked vegetables is prioritized in the menu and there is little offer of raw vegetables and fruits due to the limitations of supply and storage logistics. The insufficient offer of differentiated food is a factor that can influence food intake, because the acceptance of certain food given the frequent consumption decreases. In Brazil, the Health Department recommends in its Food Guide ${ }^{22}$ the daily consumption of three portions of fruits and three portions of vegetables, which corresponds to $400 \mathrm{~g} /$ day of these foods. The Food Guide emphasizes the importance of varying the consumption of these fruits and vegetables in meals throughout the week aiming at variety of bioactive nutrients and substances and also avoiding rejection of food due to frequent intake.

In accordance with the Brazilian recommendations, the studied population does not receive proper meals in terms of amount and variety of fruits and vegetables. The average consumption of these foods was of $193 \mathrm{~g} /$ day, less than half the amount recommended. The juices offered were artificial, not contributing to the increase of fruit intake, but contributing to higher sugar consumption. The low consumption of fruits and vegetables may influence the consumption of fibers, vitamins and minerals. 
However, this is a standard observed in the Brazilian population that shows low consumption of fruits and vegetables ${ }^{29}$.

We can observe by Table 3 that the meal weight offered during lunch is higher than the one offered for dinner. This possibly occurs because, in Brazil, lunch is the period when people have the habit to eat more, around $40 \%$ of total food ingestion ${ }^{30}$. In the case of this population, the consumption of lunch represents $48 \%$ of the daily total energetic value, which is then emphasized as the main meal. At dinner, there is a reduction in the offer and in the consumption of food. This fact is possibly due to the different service modality (self-service) and through the repetition of the same composition as lunch, which may cause rejection and jeopardize the acceptance.

In accordance to Mezomo ${ }^{31}$, when the result of the remaining portion index is higher than $10 \%$ in healthy population, we assume that menus are inappropriate because of being badly

Table 3. Average and standard deviation of weight $(\mathrm{g}$ ) of the offered meals, consumed amount and remaining portion regarding lunch and dinner in the three-day evaluation. Brazil, 2011.

\begin{tabular}{|c|c|c|c|c|}
\hline \multirow{2}{*}{ Parameters } & \multicolumn{2}{|c|}{ Lunch } & \multicolumn{2}{|c|}{ Dinner } \\
\hline & Average & SD & Average & SD \\
\hline Offer (g) & $728 \pm$ & 159 & $418 \pm$ & 111 \\
\hline Consumption (g) & $521 \pm$ & 160 & $326 \pm$ & 90 \\
\hline Remaining portions (g) & $216 \pm$ & 177 & $93 \pm$ & 80 \\
\hline Remaining portions (\%) & $29,8 \pm$ & 23,3 & $22 \pm$ & 20 \\
\hline
\end{tabular}

Note: SD: Standard Deviation. planned and/or badly executed, causing great financial damage to the meal production unit. We verified by Table 4 that the percentage of the remaining portion both at lunch and dinner is higher than the recommendation, which possibly indicates low acceptance of the offered meals. Probably the remaining portions are larger at lunch for the type of service, because individuals serve themselves at dinner, putting on their plate only what they want to consume. The remaining portion percentage at dinner is also high. The statistical analysis comparing IR demonstrates that this difference of remaining portions at lunch and dinner is significant $(p<0.05)$.

The estimate of nutrients ingestion is shown for the studied population in Table 4. Here we can verify the averages of offer and nutrients consumption calculated from the offered/ consumed meals throughout three monitoring days. The data of energy value, proteins, carbohydrates, lipids, fractions of alimentary fiber and sodium are shown.

We verified that the average energy value of meals offered throughout the day was approximately $3.636 \pm 183 \mathrm{kcal}$; the value is similar to the one found in EER recommendation for this population. However, total energy value consumed is below the recommended amount. The energy consumption is important not only for the maintenance of the body weight, but for maintenance of health. Therefore, the low energy ingestion can result in loss of muscular mass, increase of fatigue and, consequently, compromising the work productivity 32 .

Table 4. Average of nutritional composition of the meals offered/consumed by soldiers. Brazil, 2011.

\begin{tabular}{|c|c|c|c|c|c|}
\hline \multirow{2}{*}{ Nutritional Information } & \multicolumn{2}{|c|}{ Offer } & \multicolumn{2}{|c|}{ Consumption } & \multirow{2}{*}{ Recommendation } \\
\hline & Average & SD & Average & SD & \\
\hline Energy value (kcal) & $3.636=$ & \pm 183 & 3.197 & \pm 413 & 3.600 \\
\hline Carbohydrates (\%) & $70=$ & $\pm 0,5$ & 77 & $\pm 1,5$ & 45 to 65 \\
\hline Proteins (\%) & $15=$ & $\pm 0,5$ & 15 & \pm 1 & 10 to 35 \\
\hline Total fat (\%) & $15=$ & \pm 1 & 8 & $\pm 0,5$ & 20 to 35 \\
\hline Alimentary fiber (g) & 40 & $\pm 3,2$ & 31 & $\pm 1,5$ & 25 \\
\hline Sodium (mg) & $10.448=$ & \pm 1.810 & 8.626 & \pm 2.384 & 2.300 \\
\hline
\end{tabular}

Note: SD: Standard Deviation. 
Although there was appropriate prevalence of offer of calories, carbohydrates, proteins, lipids and fibers in accordance with Dietary Reference Intake's (DRI) recommendations ${ }^{21}$, the obtained results showed insufficiency for all studied variables related to the goals of nutrients ingestion by the WHO for the prevention of chronic diseases and the promotion of healthy nourishment ${ }^{22}$.

As for the energy distribution between macronutrients, we verified that the average calorie contribution of carbohydrates was approximately $77 \%$, proteins were $15 \%$ and lipid was $8 \%$. That is, carbohydrate percentage is above the recommended amount (DRI); lipids are below the minimum recommended amount and proteins are within the limit. Thus, as the consumption reflected total energy value lower than the needs, the diet is unbalanced. This means that this population can show loss of weight and muscular mass in medium and long terms, compromising the developed activities, as well as showing other diseases arising from the lower consumption.

The consumed sodium was 3.5 times higher than the amount recommended as the maximum ingestion limit for the Brazilian population. There was excess in the amount of fibers of the offer (60\%) and upon consumption (24\%). Fibers have an important role in the prevention of cardiovascular and gastrointestinal diseases and help in the prevention of chronic diseases related to the diet ${ }^{22}$, demonstrated by studies $^{29,30}$.

High amounts of fibers are derived from the high consumption of beans, a legume with high fiber amount. Still, the fiber contribution by vegetables and fruits is low, since we observed low consumption of fruit and salads with raw vegetables.

The daily sodium consumption was high (8.626 mg) when compared to Institute of Medicine recommendation ( $2.300 \mathrm{mg} /$ day), which can lead this population to various chronic diseases etiologically related to the excessive sodium intake, such as hypertension, cardiovascular diseases, heart disease, gastric cancer, osteoporosis and obesity ${ }^{33}$. Confirming this result, a study indicates that the sodium ingestion is high in Brazil, surpassing five times the daily needs ${ }^{34}$. This factor is directly related to the excessive addition of salt during preparation of food and also of the use of industrialized spices (meat broth, complete spice with salt and garlic), which contains high sodium amount. Therefore, we can suggest that natural condiments are used, such as parsley, chives, garlic, coriander, oregano, and anise.

The dishes that most contributed to the high intake of this mineral were white rice, which is consumed daily, and the main courses, that is, protein dishes. It is important a better menu planning in order to reduce waste; nutritional adequacy; less repetition of preparations and monotony of menus; reduction of high sodium spices and artificial juices; and improvement of food habits in the population. Furthermore, this demonstrates the need for job training and awareness of people that handle food. Nutritional education for soldiers is important for changes in the composition and consumption of these meals.

\section{CONCLUSION}

Since this is a population with great physical strain due to military functions, it is important to evaluate the composition of their meals. Most soldiers presented fat percentage and $\mathrm{BMI}$ within the amount recommended for the age and physical activity level.

The energetic value offer for the population was $3.636 \pm 359 \mathrm{kcal}$; it is in accordance with EER for the population ( $3.600 \mathrm{kcal}$ ). However, the consumption was only $3.197 \pm 413 \mathrm{kcal}$, which is lower to the energy needs of the population. This can be explained by the high percentage of remaining portions in the main meals (lunch and dinner), which possibly indicates low acceptance of the offered meals. 
As for the energy distribution of the consumed meals, we verified that the average calorie contribution of carbohydrate percentage was above the recommended amount (DRI); lipids below the minimum recommended amount and proteins within the recommendation limit.

As for the nutritional quality of the served meals, little offer of fruits and vegetables throughout the day was observed, which can probably lead these individuals to have some deficiency of micronutrients in the future, since these are contained in these foods.

We also observed that preparations show excessive amount of sodium, emphasizing the need for nutritional adequacy of meals which must daily provide the energy and nutrients contribution required for health, work and optimal functioning of the whole body.

Therefore, we remark the need of menus' reformulation through adequate planning for this kind of population in order to present nutritional adequacy; improvement of menu acceptance; increase of different types of preparations; inclusion of fruits and vegetables; revision of TPF to avoid high sodium spices and meals; and adequacy of nutrients' distribution. More studies are necessary to evaluate populations' demands.

The present study showed the limitation of only analyzing the adequacy of menus related to nutritional aspects, offer and consumption by Brazilian army soldiers. However, it is important to enlarge this study considering other quality aspects of menus and meals such as sensorial, hygienic, cultural, and symbolic, and sustainability.

\section{CONTRIBUTORS}

RBA BOTELHO, F AVENA, M VERAS and RP ZANDONADI designed research and analyzed data. $F$ AVENA and M VERAS conducted research. RBA BOTELHO and RP ZANDONADI wrote the paper and had primary responsibility for final content. All authors read and approved the final manuscript.

\section{R F E R E NCES}

1. Brasil. Ministério da Defesa. O exército. Brasília: Ministério da Defesa; 2012 [acesso 2012 jul 5]. Disponível em: <http://www.exercito.gov.br/ 060Ms/gabcmtex/por657.htm>.

2. Pograjc L, Stibilij V, Scanc AR, Jamnik $M$. Determination of macronutrients and some essential elements in the Slovene military diet. Food Chem. 2010; 122(4):1235-40.

3. Brasil. Lei Orgânica de Segurança Alimentar Nutricional (Losan). Lei $n^{\circ}$ 11.346, de 15 de setembro de 2006. Cria o Sistema Nacional de Segurança Alimentar e Nutricional - SISAN com vistas em assegurar o direito humano à alimentação adequada e dá outras providências. Diário Oficial da União. 2006; 18 set [acesso 2013 out 16]. Disponível em: <https://www.planalto.gov.br/ccivil_03/ Ato2004-2006/2006/Lei/L11346.htm>.

4. Diez-Garcia RW. Eating practices and behavior in the urban environment: A study in downtown São Paulo. Cad Saúde Pública. 1997; 13(3):455-67.

5. Mullins VA, Houtkooper LB, Howell WH, Going SB, Brown $\mathrm{CH}$. Nutritional Status of U.S. elite female heptathletes during training. Inter J Sport Nutr Exercise Metabol. 2001; 11(3):299-314.

6. Beshgetoor D, Jeanne FN. Dietary intake and supplement use in female master cyclists and runners. Inter J Sports Nutr. 2003; 13(2):166-72.

7. Crombie AP, Funderburk LK, Smith TJ, McGraw SM, Walker LA, Champagne CM, et al. Effects of modified foodservice practices in military dining facilities on ad libitum nutritional intake of US army soldiers. J Academy Nutr Dietetics. 2013; 113(7): 920-27.

8. American College of Sports Medicine, American Dietetic Association, Dietitians of Canada. Joint position stand: Nutrition and athletic performance. Med Sci Sports Exerc. 2000; 32(2):130-45.

9. Tharion W, Lieberman HR, Montain SJ, Young AJ, Baker-Fulco CJ, DeLany JP, et al. Energy requirements of military personnel. Appetite. 2005; 44(1):47-65.

10. Schaffer R, Mendenhall W, Ott RL, Gerow KG. Elementary survey sampling. $7^{\text {th }} \mathrm{ed}$. Boston: Brooks/ Cole; 1990.

11. World Health Organization. The world health report 2002: Reducing risks, promoting healthy life. Geneva: WHO; 2002.

12. Rossi L, Tirapegui J. Comparação dos métodos de bioimpedância e equação de Faulkner para avaliação da composição corporal em desportistas. Rev Bras Ciênc Farm. 2001; 37(2):137-42. 
13. Jellife DB. Evaluación del estado de nutrición de la comunidad. Genebra: OMS; 1968.

14. Food and Agriculture Organization. Human energy requirements. Report of a joint FAO/WHO/ONU Expert consulation. Geneva: FAO; 2001.

15. Institute of Medicine. Dietary reference intakes: The essential guide to nutrient requirements. Washington (DC): National Academy Press; 2006.

16. Camargo EB, Botelho RBA. Técnica dietética: seleção e preparo de alimentos: manual de laboratório. São Paulo: Atheneu; 2005.

17. Teixeira S, Milot Z, Carvalho J, Biscontini TM. Administração aplicada às unidades de alimentação e nutrição. São Paulo: Atheneu; 2007.

18. Núcleo de Estudos e Pesquisas em Alimentação, Universidade Estadual de Campinas. Tabela brasileira de composição de alimentos. Versão 1. Campinas: Unicamp; 2004.

19. Sávio KEO, Costa TH, Miazaki E, Schmitz BAS. Assessment of lunch served in the workers' food program, Brazil. Rev Saúde Pública. 2005; 39(2):148-55.

20. Abreu ES, Spinelli MGN, Zanardi AMP. Gestão de unidades de alimentação e nutrição: um modo de fazer. São Paulo: Metha; 2009.

21. United States of America. Department of Health and Human Services. Dietary guidelines for Americans. Washington (DC): U.S. Government Printing Office; 2005 [cited 2012 Aug 18]. Available from: <www.health.gov/DietaryGuidelines/dga 2005/document/default.htm>.

22. Brasil. Ministério da Saúde. Guia alimentar para a população Brasileira. Brasília: Ministério da Saúde; 2006.

23. Schultz DP, Schultz SE. História da psicologia moderna. 16a ed. São Paulo: Cultrix; 1992.

24. Brasil. Vigitel: Vigilância de Fatores de Risco e Proteção para Doenças Crônicas por Inquérito Telefônico. Brasília: Ministério da Saúde; 2009.

25. Piers LS, Soares MJ, Frandsen SL, O'Dea K. Indirect estimates of body composition are useful for groups but unreliable in individuals. Inter J Obesity. 2000; 24:1145-52.

26. Rezende FAC, Rosado LE, Franceschinni SC, Rosado GP, Ribeiro RC. The body mass index applicability in the body fat assessment. Rev Bras Med Exerc Esporte. 2010; 16(2):90-4.

27. Montain SJ, Young AJ. Diet and physical performance. Appetite. 2003; 40(3):255-67.

28. Silva-Junior EA. Manual de controle higiênico-sanitário dos alimentos. $6^{a}$ ed. São Paulo: Varela; 2005.

29. Jaime PC, Monteiro CA. Fruit and vegetable intake by Brazilian adults. Cad Saúde Pública. 2005; 21(1):519-24.

30. Vasconcellos MTL, Anjos LA. Energy adequacy ratio (intake/requirements) as an indicator of household nutritional assessment: A critical analysis of methods applied to food consumption surveys. Cad Saúde Pública. 2001; 17(3):581-93.

31. Mezomo IFB. O serviço de alimentação. In: Os serviços de alimentação: planejamento e administração. $4^{\text {a }}$ ed. São Paulo: Manole; 2002.

32. Ainsworth B, Haskell W, Whitt M, Irwin ML, Swartz AM, Strath SJ, et al. Compendium of physical activities: Classification of energy cost of human physical activities. Med Sci Sports Exerc. 2000; 32(9):498-516.

33. Campbell N, Correa-Rotter R, Neal B, Cappuccio FP. New evidence relating to the health impact of reducing salt intake. Nutr Metabol Cardiov Dis. 2011; 21(9):617-9.

34. Instituto Brasileiro de Geografia e Estatística. Pesquisa domiciliar sobre comportamentos de risco e morbidade referida de doenças e agravos não transmissíveis. Brasília: Ministério da Saúde; 2012.

Received on: 2/7/20013 Final version on: 10/7/2013 Approved on: 1/17/2014 
